SOSIOLIUM

\title{
PEMANFAATAN MEDIA POP UP BOX DALAM PEMBELAJARAN IPS DI SMP BHAKTI KUDUS
}

\author{
Maulina Rahma Dewi, Aisyah Nur Sayidatun Nisa ${ }^{\varpi}$ \\ Prodi Pendidikan Ilmu Pengetahuan Sosial, Fakultas Ilmu Sosial, Universitas Negeri Semarang, Indonesia
}

\begin{abstract}
Info Artikel Abstrak
\section{Sejarah Artikel:}

Disubmit: Juli 2021

Direvisi: Agustus 2021

Diterima: September

2021

Keywords:

Pop Up Box Media,

Social Studies Learning

Penelitian ini bertujuan untuk: 1) Mengetahui bentuk pemanfaatan media Pop $U p$ Box dalam pembelajaran IPS di SMP Bhakti Kudus. 2) Mengetahui faktor pendorong dan penghambat dalam pemanfaatan media Pop Up Box didalam Proses pembelajaran IPS di SMP Bhakti Kudus. Penelitian ini menggunakan metode penelitian kualitatif. Hasil penelitian ini menunjukan bahwa: 1) Pemanfaatan media Pop Up Box di dalam pembelajaran IPS di SMP Bhakti Kudus dilaksanakan melalui tiga tahap. Tahap pertama, yaitu tahap perencanaan, Tahap kedua, yaitu tahap pelaksanaan. Pada tahap terakhir yaitu tahap evaluasi. 2) Pemanfaatan media Pop $U p$ Box menemui beberapa faktor pendukung dan penghambat. Adanya media Pop $U p$ Box dapat meningkatkan kualitas pembelajaran IPS. Sedangkan untuk faktor penghambat penggunaan media adalah dari segi sekolah, guru, dan peseserta didik.
\end{abstract}

\begin{abstract}
This study aims to: 1) Determine the form of the use of Pop Up Box media in social studies learning at SMP Bhakti Kudus. 2) Knowing the driving and inhibiting factors in the use of Pop Up Box media in the Social Studies learning process at SMP Bhakti Kudus. This study used qualitative research methods. The results of this study indicate that: 1) The use of Pop Up Box media in social studies learning at SMP Bhakti Kudus is carried out in three stages. The first stage, namely the planning stage, the second stage, namely the implementation stage. The last stage is the evaluation stage. 2) The use of Pop Up Box media encountered several supporting and inhibiting factors. The existence of Pop Up Box media can improve the quality of social studies learning. Meanwhile, the inhibiting factors for the use of media are in terms of schools, teachers, and students.
\end{abstract}

\footnotetext{
Alamat korespondensi:

Gedung C1 Lantai 1 FIS Unnes

Kampus Sekaran, Gunungpati, Semarang, 5022

Email: aisyah8816@mail.unnes.ac.id
} E-ISSN 2685-4929 


\section{PENDAHULUAN}

Undang-undang Republik Indonesia Nomor 20 Tahun 2003 Pasal 1 berbunyi "pendidikan adalah usaha sadar dan terencana untuk mewujudkan suasana belajar dan proses pembelajaran agar peserta didik secara aktif mengembangkan potensi dirinya untuk memiliki kekuatan spiritual keagamaan, pengendalian diri, kepribadian, kecerdasan, akhlak mulia, serta keterampilan yang diperlukan dirinya, masyarakat, bangsa dan Negara". Sistem pendidikan nasional telah ditetapkan bahwa pendidikan nasional telah berfungsi mengembangkan kemampuan dan membentuk watak serta peradaban bangsa yang bermartabat dalam rangka mencerdaskan kehidupan bangsa, bertujuan untuk berkembangnya potensi peserta didik agar menjadi manusia yang beriman dan bertakwa kepada Tuhan Yang Maha Esa, berakhlak mulia, sehat, berilmu, cakap, kreatif, mandiri, dan menjadi warga Negara yang demokratis serta bertanggung jawab idealnya fungsi utama pendidikan yaitu mempersiapkan generasi. Salah satu jenjang pendidikan yang menjadi tempat pelaksanaan pembelajaran ialah sekolah menengah pertama. Salah satu sekolah menengah pertama yang terdapat di daerah kudus ialah SMP Bhakti Kudus.

SMP Bhakti Kudus terletak di jalan Kyai Mojo, kelurahan Mlati Kidul Kabupaten Kudus. Berdasarkan hasil observasi awal di SMP tersebut memiliki sarana prasarana berupa ruang kelas, ruang guru, musholla, perpustakaan, kantin, UKS, dan sebagainya. Tapi dalam pemanfaatannya sarana dan prasarana yang dimiliki sekolah belum dimanfaatkan secara maksimal dan terdapat sejumlah prasarana yang terbatas seperti proyektor, LCD, Wifi. Keterbatasan tersebut dapat memberikan dampak kurangnya ketercapaian ranah kognitif, psikomotorik, dan afektif peserta didik dalam pembelajaran di kelas. Hal tersebut sesuai dengan peryataan dari Ibu Annisa Yuni Mardyana selaku guru IPS di sekolah yang menyatakan bahwa "Media yang dimiliki oleh guru di sekolah ini masih minim dan hanya sebatas menggunakan papan tulis". Peryataan tersebut memberikan gambaran bahwa perlu sebuah media yang sederhana namun dapat menunjang proses pembelajaran yang akan dilaksanakan nantinya. Media sederhana tersebut berarti media yang mampu dibuat sendiri oleh guru atau peserta didik dan tentu saja dengan biaya yang terjangkau.

Pemanfaaatan media sederhana tersebut diharapkan dapat diterapkan dalam sejumlah mata pelajaran dan tentu saja disesuaikan dengan materi yang ada. Salah satu mata pelajaran yang memerlukan media sederhana namun interaktif yaitu mata pelajaran ilmu pengetahuan sosial (IPS) dimana mata pelajaran IPS sejatinya merupakan perpaduan antara ilmu sosial seperti geografi, ekonomi, sosiologi, dsb. Selain itu, didalam mata pelajaran IPS terdapat dimensi tertentu yang membahas ranah dari IPS. Dimensi didalam IPS terdapat empat buah dimensi antara lain dimensi pengetahuan, keterampian, nilai dan sikap, serta dimensi tindakan (Sapriya:2019).

Tuntutan ketercapaian ranah kognitif, psikomotorik, dan efektif tentunya menjadi sebuah penghambat ketika sarana dan prasarana yang dimiliki sekolah masih minim terlebih ketika media yang digunakan dalam pembelajaran masih terbatas. Untuk itu perlu sebuah media inovatif namun sederhana seperti media Pop Up Box. Pemilih media pembelajaran, tentu ada beberapa prinsip yang digunakan sesuai dengan medianya. Wati (2016:17) mengemukakan bahwa prinsip-prinsip media pembelajaran adalah Media pembelajaran digunakan dengan tujuan yang jelas, Suatu media pembelajaran dipilih untuk menyampaikan materi dengan tepat sesuai kebutuhan dan pemilihan media pembelajaran harus secara objektif. Pemilihan media harus benar-benar didasari dengan pertimbangan yang matang.

Media Pop Up Box merupakan media yang berbentuk kotak, ketika kotak tersebut dibuka, keempat sisi dari kotak tersebut akan membentuk jaring-jaring kotak dan memunculkan tulisan atau gambar menurut tema Nasriya (2018:25). Kelebihan dari media tersebut antara lain Meningkatkan rasa ingin tahu dengan cara mengisi konten kotak tersebut dan perasaan terkejut ketika membukanya, Adanya gambar dan tulisan menarik yang dapat dibuka dan ditarik serta dapat memberi ketertarikan dalam kotak tersebut, Dapat diisi dengan berbagai macam benda dalam bentuk gambar atau tulisan sesuai kebutuhan.

Mengetahui hal tersebut maka diharapkan melalui pemanfaatan media Pop Up Box dapat menunjang ketercapaian ranah kognitif, psikomotorik, dan efektif peserta didik didalam mata pelajaran IPS. pemanfaatan media tersebut diharapkan dapat menutupi kekurangan sekolah dalam sarana prasarana yang dimiliki melalui media pembelajaran. Pada akhirnya melalui media tersebut diharapkan mampu menunjang Ketercapaian peserta didik sehingga dapat menunjang 
ketercapaian tujuan pendidikan yang tertuang didalam UU No 20 tahun 2003.

Penelitian ini bertujuan untuk: (1) Mengetahui bentuk pemanfaatan media Pop Up Box dalam pembelajaran IPS di SMP Bhakti Kudus. (2) mengetahui faktor pendorong dan pemnghambat dalam pemanfaatan media $P o p$ Up Box di dalam proses pembelajaran IPS di SMP Bhakti Kudus.

\section{METODE}

Penelitian ini termasuk dalam penelitian dengan pendekatan kualitatif dimana penelitian ini dilaksanakan di SMP Bhakti Kudus. SMP Bhakti Kudus merupakan sekolah swasta, yang belum memaksimalkan sarana dan prasarana sekolah dalam hal media pembelajaran. Oleh karena itu, peneliti ingin mengetahui bagaimana peningkatan keaktifan yang terjadi di SMP Bhakti Kudus melalui pemanfaatan media Pop Up Box dalam pembelajaran IPS yang dilaksanakan di kelas VIII SMP Bhakti Kudus. Pelaksanaan penelitian ini di mulai bulan September 2020. Dalam proses penelitian, peneliti mendatangi langsung di sekolah. Penelitian secara langsung berguna untuk memperoleh data yang diperlukan dan penelitian akan berakhir ketika peneliti merasa data yang diperoleh dirasa cukup.

Penelitian kualitatif merupakan sebuah siklus yang diawali dari pemilihan masalah, dilanjutkan dengan pembuatan pertanyaan, membuat catatan atau perekaman dan kemudian di analisis (Sudrajat, 2005:19). Jadi dapat dikatakan bahwa masalah yang ada didalam penelitia kualitatif dilakukan berdasarkan data yang relevan. Masalah didalam penelitian ini disebut sebagai fokus penelitian. Fokus penelitian memiliki tujuan agar 1) penetapan fokus dapat membatasi studi, 2) penetapan fokus itu berfungsi untuk memenuhi kriteria inklusi ekslusi atau memasukan mengeluarkan suatu informasi yang baru diperoleh di lapangan (Moleong 2007:94). Maka dari itu yang menjadi fokus penelitian disini adalah bagaimana pemanfaatan media $P o p \quad U p$ Box dalam pembelajaran IPS di SMP Bhakti Kudus sebagai salah satu cara peningkatan keaktifan peserta didik.

Sumber data yang dgunakan dalam penelitian ini adalah sumber data primer dan sumber data sekunder. Sumber data primer meliputi teknik observasi dan wawancara. eknik observasi dilaksanakan dengan pengamatan secara langsung yang dilakukan oleh peneliti sementara, teknik wawancara dilakukan dengan mewawancarai informan terkait. Beberapa informan yang dipilih dalam penelitian ini antara lain guru IPS kelas VIII , Kepala Sekolah, Wakil Kurikulum, serta peserta didik kelas VIII di SMP Bhakti Kudus. Sumber data sekunder dalam penelitian ini diperoleh melalui teknik dokumentasi berupa buku-buku, jurnal, peraturan perundang undangan, RPP guru, dan dokumen terkait. Teknik pengumpulan data dilakukan dengan cara observasi, wawancara dan dokumentasi. Wawancara dilakukan secara langsung dengan informan kepala sekolah SMP Bhakti kudus, guru mata pelajaran IPS, wakil kepala sekolah bidang kurikulum dan peserta didik kelas VIII SMP Bhakti Kudus. Uji validitas data yang digunakan dalam penelitian ini adalah triangulasi teknik. Uji keabsahan data yang digunakan dalam penelitian ini adalah model analisis interaktif Miles Huberman yaitu pengumpulan data, reduksi data, penyajian data dan penarikan kesimpulan/Verifikasi.

\section{HASIL DAN PEMBAHASAN}

SMP Bhakti Kudus merupakan salah satu sekolah swasta yang terletak di Kel. Mlati Kidul Rt 01/01, Kecamatan Kota, Kabupaten Kudus. SMP Bhakti Kudus terletak di daerah perkotaan dengan jarak $3 \mathrm{~km}$ dari pusat kota Kudus. Masyarakat sekitar rata-rata berprofesi sebagai buruh pabrik, petani, dan wirausaha. Sebagian besar masyarakat adalah masyarakat kelas menengah kebawah. SMP Bhakti Kudus berdiri sejak tahun 1975 dalam SK No. 12/PEND/YPNI/1975 dan terakreditasi B. Saat ini kepala sekolah di kepalai oleh Bapak Yudi Susilo,A.Ma.Pd. SMP Bhakti Kudus sendiri memiliki jumlah peserta didik 75 peserta didik yang terdiri dari kelas tujuh 14 orang peserta didik, kelas delapan sebanyak 29 orang peserta didik, dan kelas Sembilan 32 orang peserta didik. Memiliki tenaga pendidik sejumlah 12 guru dan ditambah 3 tenaga tata usaha serta satu orang penjaga sekolah. Adapun keadaan guru di SMP Bhakti Kudus berdasarkan data yang di himpu berjumlah 12 orang guru yang terdiri tujuh orang guru perempuan dan lima guru laki-laki. Sarana dan prasarana cukup memadai dengan rincian yaitu: 1) lima ruang kelas, 2) ruang kepala sekolah, 3) ruang guru, 4) Musholla, 5) Perpustakaan, 6) Ruang BK, 7) Kantin, 8) Toilet, 9) UKS, 10) ruang TU dan ruang serba guna. 
Bentuk Pemanfaatan Media Pop Up Box Dalam Pembelajaran IPS di Kelas VIII SMP Bhakti Kudus

\section{Perencanaan Pembelajaran IPS}

Perencanaan pembelajaran merupakan suatu kegiatan wajib yang dilakukan oleh guru untuk merancang bagaimana pembelajaran akan dilakukan agar mendapatkan hasil yang maksimal. Sebagai salah satu daerah Kabupaten yang terdampak Covid-19, seluruh pembelajaran di Kabupaten Kudus dilaksanakan secara daring, akan tetapi ada beberapa sekolah yang masih menggunakan sistem tatap muka dalam proses pembelajaran hal ini di sebabkan adanya ketidak setujuan wali murid untuk melakukan kegiatan proses pembelajaran di sekolah secara daring di berbagai sekolah di kudus. Salah satu sekolah yang masih menggunakan sistem tatap muka ialah SMP Bhakti Kudus dengan menerapkan protocol kesehatan. Untuk kurikulum yang digunakan ialah kurikulum darurat. Kurikulum darurat adalah kurikulum yang lebih menekankan kepada pengembangan karakter, akhlak mulia, dan kemandirian peserta didik. Dalam kurikulum ini satuan pendidikan dapat mengembangkan pembelajaran yang lebih kreatif dan inovatif sesuai dengan kebutuhan dan kondisi masing-masing. Adanya himbauan dari pemerintah pusat terkait kurikulum darurat yang harus diterapkan sekolah pada masa pandemi, terdapat perbedaan dalam penyusunan perencanaan pembelajarnnya. Perbedaan tersebut dimulai dari RPP yang berjumlah satu lembar, dan proses pembelajaran yang dibatasi jika menggunakan sistem tatap muka. Tahap perencanaan pembelajaran, merupakan tahap awal guru mempersiapkan perangkat pembelajaran yang berupa program tahunan, program semester, silabus, dan juga Rencana Perangkat Pembelajaran (RPP). Berdasarkan hasil observasi, dokumentasi berupa RPP dan didukung denga hasil wawancara narasumber dapat disimpulkan bahwa penyusunan RPP oleh guru dilakukan secara mandiri dengan beberapa pertimbangan seperti, hasil musyawarah MGMP, sarpras sekolah, dan kondisi sekolah yang dilakukan secara tatap muka. RPP satu lembar yang dibuat harus mencakup identitas pembelajaran, tujuan pembelajaran, media dan sumber belajar, langkah-langkah pembelajaran, materi pembelajaran, serta penilaian hasil pembelajaran. Didalam proses penyusunan
RPP dimana guru merencanakan berbagai komponen, komponen tersebut antara lain :

\section{a. Sumber Belajar}

Sumber belajar yang digunakan berupa buku paket dan LKS sebagai sumber utama, dan sumber penunjang lainya. Penggunaan sumber belajar berupa buku paket dan LKS sebagai sumber utama dalam pembelajaran bertujuan untuk menunjang ketercapaian ranah kognitif peserta didik dimana diharapkan peserta didik dapat memahami dan memperoleh wawasan secara tekstual dan kemudian wawasan tersebut dikembangkan menggunakan sumber lain berupa internet dan lingkungan. Berdasarkan hasil wawancara dengan Ibu Anisa guru IPS kelas VIII dan Bapak Yudi selaku kepala sekolah SMP Bhakti Kudus menyebutkan bahwa biasa yang dipake buku paket, LKS, terus kadang pakai internet. Pernyataan tersebut memberikan gambaran bahwa sumber belajar yang digunakan dalam pembelajaran IPS berupa buku paket, LKS, intenet, dan lingkungan

\section{b. Metode}

Metode yang digunakan dalam mata pelajaran di SMP Bhakti terlebih mata pelajaran IPS berupa metode ceramah yang dipadukan dengan diskusi dan Tanya jawab. Pemilihan metode ceramah sebagai metode yang digunakan sudah melalui berbagai pertimbangan baik dari mempertimbangkan kemampuan guru, sarana prasarana, kemampuan peserta didik, dsb. Ibu Anisa selaku guru IPS kelas VIII yang menyatakahan bahwa kalau metode sendiri saya jujur sering pake ceramah, terkadang juga melontarkan tanya jawab biar peserta didik tidak ngantuk dan bosan.

\section{c. Media Pembelajaran}

Sebelumnya menggunakan media berupa papan tulis yang disediakan oleh sekolah namun setelah mengetahui media lain yang dirasa lebih lebih baik maka guru mencoba media tersebut. Media tersebut ialah media Pop $U p$ Box di mana setelah menggunakan media Pop Up Box diharapkan dapat meningkatkan dan mengoptimalkan proses pembelajaran melalui peningkatan keaktifan peserta didik. Bapak Eko selaku wakil kepala sekolah bidang kurikulum juga memberikan pendapat serupa di mana menyatakan bahwa media tersebut dapat mencuri perhatian seperti peserta didik dapat mudah mencerna apa yang guru sampaikan karena setau saya media tersebut terdapat gambar yang menarik, sehingga mempermudahkan peserta didik dalam kegiatan pembelajaran di kelas. 


\section{Perencanaan}

Proses pelaksanaan pembelajaran terdapat tiga tahap yakni kegiatan pendahuluan, inti dan penutup.Pertama, kegiatan pembelajaran IPS dimulai dengan kegiatan pendahuluan dimana guru mengajak peserta didik untuk berdoa, kemundian melakukan apresepsi, menyampaiakan tujuan pembelajaran, dan memberikan sejumlah motivasi. Kegiatan pendahuluan disini bertujuan untuk memusatan perhatian peserta didik kepada guru sebelum guru mulai menyampaikan materi yang berkaitan, selain itu kegiatan pendahuluan juga ditujukan untuk memberikan motivasi dan semangat kepada peserta didik agar selama proses pembelajaran peserta didik lebih antusias. Selanjutnya pada kegiatan inti guru menyampaikan sekilas materi melalui isi dari media Pop Up Box yang dimana terdapat materi interaksi keruangan dalam Negara Negara ASEAN sub bab karakteristik Negara Laos yang di buat secara menarik dan mudah dipahami oleh peserta didik.

Selanjutnya guru memperlihatkan media tersebut di depan kelas, dalam penelitian ini peneliti melihat ada beberapa peserta didik sudah memperhatikan guru dan media yang di gunakan, ada yang merasa ingin tahu tentang media tersebut dan maju ke depan kelas serta bertanya ke guru. Guru menyampaikan informasi yang terdapat di media Pop Up Box mengenai materi karakteristik Negara laos seperti letak geografis, bentang alam, iklim dan cuaca Negara Laos, keadaan penduduk, mata pencaharian dan lain lain dimana secara garis besar, terkadang guru melemparkan pertanyaan terkait kepada peserta didik, dan peserta didik merespon terkait pertanyaan yang dilontarkan oleh guru. Setelah itu dalam proses pemahaman peserta didik di berikan sejumlah kotak surat yang didalamnya berisikan perintah untuk mengerjakan bersama kelompok masingmasing dimana dalam satu kelompok terdiri dari 5-6 orang. Dikarenakan situasi pandemi Covid-19 untuk kegiatan kelompok dilakukan dengan sistem satu lajur kebelakang bangku dan untuk tempat duduk masih sama, hal tersebut dilakukan agar terhindar dari kerumunan yang menyebabkan salah satu cara penularan virus Covid-19. Setelah peserta berdiskusi setiap kelompok menunjuk satu perwakilan untuk membacakan di depan kelas terkait hasil diskusi yang telah dikerjalan bersama anggota kelompok lainnya.

Terakhir pada kegiatan penutup, guru mengulas kembali sejumlah materi yang sudah disampaikan tadi dan menanyakan terkait pemahaman peserta didik. Kemudian guru memberikan sejumlah motivasi diakhir, dan menyimpulkan materi yang sudah dipelajari bersama serta diakhiri dengan salam dan berdoa.

\section{Evaluasi Pembelajaran IPS}

Evaluasi pembelajaran merupakan proses menentukan tingkat pencapaian tujuan pembelajaran yang telah ditentukan. Berdasarkan hasil wawancara dengan Ibu Anisa sebagai guru mata pelajaran IPS kelas VIII menyebutkan bahwa ada tiga, ranah kognitif, psikomotorik, dan afektif. Evaluasi dalam ranah kognitif secara umum dilaksanakan pada saat UTS dan UAS. Sementara, evaluasi dalam ranah kognitif harian sesuai dengan karakteristik guru dan di dalam mata pelajaran IPS kelas VIII evaluasi kognitif dilaksanakan dengan rangkuman dan Tanya jawab.

Berkaitan dengan evaluasi kognitif bahwa setelah diterapkan media Pop Up Box, pemahaman peserta didik lebih meningkat dibandingkan dengan tanpa menggunakan media Pop Up Box. Peningkatan kognitif setelah menggunakan media Pop $U p$ Box tersebut berdasarkan wawancara dengan guru mata pelajaran IPS setelah menggunakan media Pop Up Box peserta didik menjadi lebih memahami isi materinya. Contohnya ketika guru mata pelajaran IPS menunjukan foto Presiden Laos, peserta didik langsung tau namanya dan kedudukannya di Negara tersebut. Evaluasi dalam ranah psikomotorik dilakukan dengan pengamatan langsung saat proses pembelajaran berlangsung, dan pihak sekolah memberi kebebasan kepada guru mata pelajaran untuk melakukan evaluasi dalam ranah psikomotorik sesuai dengan karakteristik guru. Pemanfaatan media Pop Up Box memberikan sejumlah peningkatan dalam psikomotorik atau tingkat keaktifan peserta didik saat pembelajaran, dimana hal tersebut dapat dilihat melalui keaktifan peserta didik saat bertanya terkait materi yang disampaikan pada saat guru menjelaskan menggunakan media Pop Up Box, pemberian tugas secara kelompok, diskusi terkati materi, dan pada saat guru melemparkan sejumlah pertanyaan.

Evaluasi pada ranah afektif dilakukan dengan penilaian sikap pada saat pembelajaran sesuai dengan lampiran penilaian sikap di dalam RPP. evaluasi dalam ranah afektif dilakukan dengan cara pengamatan sikap-sikap tertentu sesuai dengan lembar penilaian sikap yang sudah dirumuskan didalam RPP. Sementara terkait sekolah tidak memberikan arahan secara detail terkait teknis pelaksanaan 
evaluasi dalam ranah afektif dan cenderung memberikan kebebasan kepada guru untuk melakukan evaluasi tersebut.

Berdasarkan hasil penelitian mengenai evaluasi dalam pembelajaran IPS dapat disimpulkan bahwa didalam pembelajaran terdapat tiga ranah evaluasi yaitu evaluasi dalam ranah kognitif, psikomotorik, dan afektif. Evaluasi yang dilakukan setiap guru memiliki karakteristik dan caranya masing-masing dan sekolah memberi kebebasan terkait cara pelaksanaan evaluasi tersebut. Didalam mata pelajaran IPS kelas VIII yang diampu oleh Ibu Anisa selaku guru mata pelajaran IPS kelas VIII evaluasi dalam ranah kognitif dilaksanakan dengan pengamatan langsung sementara setelah menggunakan media Pop $U p$ Box terdapat peningkatan pemahaman peserta didik. Selanjutnya, evaluasi dalam ranah psikomotorik dilaksanakan dengan pengamatan secara langsung terhadap keaktifan peserta didik selama kegiatan pembelajaran. Sementara setelah menggunakan media Pop Up Box terdapat peningkatan keaktifan peserta didik. Terakhir, evaluasi dalam ranah afektif dilaksanakan dengan pengamatan sikap-sikap tertentu selama kegiatan pembelajaran. Sementara setelah menggunakan media Pop Up Box tidak memberikan dampak atau peningkatan tertentu dikarenakan media Pop $U p$ Box lebih berfokus kepada kognitif dan psikomotorik peserta didik.

\section{Faktor Pendukung Dan Penghambat Pemanfaatan Media Pop Up Box Didalam Proses Pembelajaran Pelajaran IPS Di Kelas VIII SMP Bhakti Kudus}

Media Pop Up Box merupakan media visual Penggunaan media tersebut bertujuan untuk menunjang proses pembelajaran sehingga dapat meningkatkan pemahaman dan keaktifan peserta didik selama proses kegiatan pembelajaran berlangsung. Pemanfaatan media Pop Up Box di rasa tepat karena dapat diselingi dengan metode ceramah serta diskusi, dan sumber belajar guru IPS berupa buku paket IPS dari pemerintah dan buku LKS peserta didik yang dimana buku tersebut dari sekolah. Adanya pemanfaatan media dapat meningkatkan pemahaman dan keaktifan peserta didik selama proses kegiatan pembelajaran berlangsung. Pemanfaatan media Pop Up Box di rasa tepat karena dapat diselingi dengan metode ceramah serta diskusi, dan sumber belajar guru IPS sehingga muncul interaksi antara guru dan peserta didik, mempermudah peserta didik dalam proses penyampaian materi pembelajaran, dapat dilihat berkali- kali jika mau menggunakannya dan mudah di simpan, analisa lebih tajam dapat membuat peserta didik lebih faham isi materi tersebut dengan menganalisis yang lebih mendalam dan dapat membuat orang berpikir lebih spesifik tentang isi tulisan. Media Pop $U p$ Box dapat diterapkan didalam pembelajaran dan dapat meningkatkan kognitif dan psikomotorik peserta didik namun didalam penerapan media Pop Up Box menemui sejumlah kendala, kendala tersebut antara lain :

Keberadaan sarana prasarana akan menunjang proses pembelajaran di suatu sekolah, berdasarkan hasil penelitian diketahui bahwa sarana prasarana yang dimiliki sekolah tergolong kurang hal ini dapat dilihat dari hasil observasi terkait sarana prasarana yang dimiliki sekolah. Berdasarkan hasil wawancara dengan Ibu Anisa yang menyatakan bahwa" Belum mengoptimalkan penunjang pembelajaran dari segi prasarana dan prasarana dalam hal ini fasilitas belajar di kelas. Selain keterbatasan fasilitas penunjamg belajar dalam hal ini media pembelajaran yang diterapkan di kelas, keterbatasan kemampuan peserta didik dalam menerima materi pembelajaran. Ibu Anisa sebagai guru mata pelajaran IPS kelas VIII menjelaskan bahwa Sekolah disini bukan tergolong sekolah favorit, jadi anak-anak seadanya, ada yang bias dengan cepat dan mudah memahami materi, dan ada juga yang belum bisa. Rata-rata anak yang bersekolah disini dulu tidak diterima di sekolah favorit. Ibu Anisa selaku guru mata pelajaran IPS kelas VIII menjelaskan bahwa karakteristik setiap peserta didik berbeda dalam tingkat pemahaman memahami materi pembelajaran serta potensi peserta didik yang berbeda. Pendapat tersebut sesuai dengan pernyataan Bapak Eko selaku wakil kepala sekolah bidang kurikulum yang berpendapat bahwa untuk SMP Bhakti sendiri dengan karakter peserta didik yang rata-rata sulit kurang mampu dalam tingkat pemahaman serta sekolah juga tergolong bukan sekolah favorit di daerah Kudus. Selanjutnya dari segi penyampaian materi dengan menggunakan media Pop Up Box guru belum terampil dalam menggunakan media tersebut, merasa gugup dan bingung dalam menggunakan media kadang masih terbata bata dalam penggunaan media tersebut. Hal tersebut sesuai dengan pendapat peserta didik yang bernama Ardian kelas VIII yang mengatakan bahwa ketika pelajaran $\mathrm{Bu}$ Anisa terlihat bingung mau darimana menjelaskan materi yang ada di dalam $P o p$ Up Box, selanjutnya meminta 
bantuan ke peneliti untuk memastikan mau bagian mana dulu yang disampaikan. Ibu Anisa yang menyatakan" untuk kegiatan pembelajaran dengan menggunakan media $P o p$ $U p$ Box, jujur saya kurang terampil dalam penggunaannya, kadang masih terbata bata dalam penggunaan media tersebut.

\section{PEMBAHASAN}

\section{Pemanfaatan Media Pop Up Box dalam pembelajaran IPS di SMP Bhakti Kudus}

Mata pelajaran IPS merupakan mata pelajaran integrasi dari mata pelajaran Sejarah, Geografi, dan Ekonomi serta mata pelajaran ilmu sosial lainnya (Sapriya, 2019:7). Mata pelajaran IPS ditemukan pada tingkat Sekolah Dasar sampai perguruan tinggi. Namun, di setiap jenjang pendidikan mempunyai takaran yang berbeda. Perbedaan tersebut terlihat dari penggabungan bidang studi Sejarah, Ekonomi, Geografi, dan Sosiologi menjadi satu mata pelajaran yang disebut dengan IPS Terpadu. Sumantri (2001:92) dalam Sapriya pendidikan IPS adalah seleksi dari disiplin ilmu-ilmu sosial dan humaniora, serta kegiatan dasar manusia yang diorganisasikan dan disajikan secara ilmiah dan psikologis untuk tujuan pendidikan. Didalam proses pembelajaran IPS dilaksanakan melalui tiga tahapan kegiatan.

\section{Tahap perencanaan}

Perencanaan pembelajaran dilakukan oleh guru dimulai dengan menyusun perangkat pembelajaran berupa progam tahunan (prota), progam semester (Promes), silabus, dan rencana pelaksanaan pembelajaran (RPP) (Lestari Puji,dkk : 2019). Berdasarkan hasil penelitian di SMP Bhakti Kudus dalam tahap perencanaan sudah sesui dengan teori yang dikemukakan oleh ahli. Didalam proses penyusunan RPP dimana guru merencanakan berbagai komponen, komponen tersebut antara lain:

\section{a. Sumber belajar}

Sanjaya (2010:174) mengartikan bahwa sumber belajar adalah segala sesuatu yang dapat dimanfaatkan oleh peserta didik untuk mempelajari bahan dan pengalaman belajar yang bertujuan untuk menunjang ketercapaian tujuan pendidikan, dimana berdasarkan hasil penelitian yang dilakukan SMP Bhakti Kudus pada mata pelajaran IPS menggunakan sumber belajar berupa buku paket, internet, dan lingkungan. Penggunaan buku paket sebagai sumber utama didalam pembelajaran dan ditunjang oleh sumber lainnya sesuai dengan karakteristik guru dalam pembelajaran dan kemampuan dari peserta didik itu sendiri. Dengan demikian dapat disimpulkan bahwa hasil penelitian dimana penggunaan sumber belajar berupa buku paket, internet, lingkungan sesuai dengan teori yang dikemukakan oleh ahli.

\section{b. Metode belajar}

Hamalik (2010) menyatakan bahwa metode adalah suatu cara yang digunakan untuk menyampaikan materi pelajaran dalam upaya mencapai tujuan, dimana berdasarkan hasil penelitian dilakukan di SMP Bhakti Kudus metode yang digunakan dalam pemanfaatan media Pop Up Box ialah ceramah, tanya jawab, diskusi kelompok. Pemilihan metode tersebut dirasa lebih cocok jika diterapkan saat pembelajaran IPS di SMP Bhakti Kudus pada pembelajaran IPS materi interaksi keruangan negara negara ASEAN sub bab karakteristik negara Laos pada kelas VIII. Dengan demikian dapat disimpulkan bahwa hasil penelitian dimana penggunaan metode belajar sesuai dengan teori yang dikemukakan oleh ahli c. Media

Smaldino, dkk (2008) mendefinisikan media adalah segala sesuatu yang menyampaikan informasi dari sumber kepada penerima. Pemilihan media disesuaikan dengan keadaan sekolah dan karakteristik guru dalam menyampaikan materi, pihak sekolah membebaskan guru untuk memilih media yang dirasa sesuai sehingga guru dapat memaksimalkan potensi dari sebuah pembelajaran sehingga tercipta ketercapaian tujuan pendidikan.Berdasarkan hasil penlitian diketahui bahwa di sekolah SMP Bhakti Kudus media yang digunakan ialah $P o p \quad U p \quad B o x$ dikarenakan dirasa sangat efektif dan dapat mempermudah pnyampaian materi lewat gambar dan isi materi yang di ringkas, lebih menarik perhatian peserta didik. Hal ini sesuai pendapat wati (2016) . Pembelajaran akan lebih menarik perhatian peserta didik, sehingga dapat menumbuhkan keaktifan, psikomotorik, dan kognitif peserta didik. Penggunaan media $P o p$ Up Box sangat membantu dikarenakan: (1) Materi jelas Materi pembelajaran akan lebih jelas maknanya, sehingga dapat lebih dipahami oleh peserta didik. (2) Tidak mudah bosan, metode yang dipakai dalam proses belajarmengajar akan lebih bervariasi, tidak sematamata komunikasi verbal dari penuturan seorang guru. (3) Peserta didik lebih Aktif, peserta didik dapat lebih banyak melakukan kegiatan belajar. Sebab, peserta didik tidak hanya mendengarkan guru, akan tetapi juga aktif dalam sebuah 
kegiatan tanya jawab dan diskusi kelompok, seperti mengamati, melakukan demonstrasi, dan lain sebagainya. Dengan demikian dapat disimpulkan bahwa pemanfaatan media Pop Up Box dinilai efektIf sebagai media pembelajaran karena dengan menggunakan media tersebut peserta didik dapat dengan mudah memahami isi materi dan dapat dengan mudah bagi guru dalam penyampaian materi kepada peserta didik dalam proses pembelajaran IPS di SMP Bhakti Kudus.

\section{Tahap pelaksanaan}

Nana Sudjana (2010) menyebutkan bahwa Pelaksanaan pembelajaran adalah proses yang diatur sedemikian rupa menurut langkah langkah tertentu agar pelaksanaan mencapai hasil yang diharapkan. Dalam pelaksanaan pembelajaran, guru melakukan beberapa tahap pelaksanaan pembelajaran antara lain:

Mebuka pelajaran Kegiatan membuka pelajaran adalah kegiatan yang dilakukan oleh guru untuk menciptakan suasana pembelajaran yang memungkinkan peserta didik siap secara mental untuk mengikuti kegiatan pembelajaran.pada kegiatan ini guru harus memperhatikan dan memenuhi kebutuhan peserta didik sertamenunjukan adanya kepedulian yang besar terhadap keberadaan peserta didik. Dalam membuka pelajaran guru biasanya membuka dengan salam dan presensi peserta didik, dan menanyakan tentang materi sebelumnya, Penyampaikan Materi Pembelajaran, Penyampaian materi pembelajaran merupakan inti dari suatu proses pelaksanaan pembelajaran. Dalam penyampaian materi guru menyampaikan materi berurutan dari materi yang paling mudah terlebih dahulu,untuk memaksimalkan penerimaan peserta didik terhadap materi yang disampaikan guru maka guru menggunakan metode mengajar yang sesuai dengan materi dan menggunakan media sebagai alat bantu penyampaian materi pembelajaran. Tahap menutup Pembelajaran. Menutup Pembelajaran Kegiatan menutup pelajaran adalah kegiatan yang dilakukan guru untuk mengahiri kegiatan inti pembelajaran. Dalam kegiatan ini guru melakukan evaluasi terhadap materi yang telah disampaikan.

Berdasarkan hasil penelitian di SMP Bhakti Kudus, diketahui bahwa kegiatan pendahuluan dimulai dari kegiatan pendahuluan pembelajaran IPS dimulai dengan kegiatan pendahuluan dimana guru mengajak peserta didik untuk berdoa, kemundian melakukan apresepsi, menyampaiakan tujuan pembelajaran, dan memberikan sejumlah motivasi. Kegiatan pendahuluan disini bertujuan untuk memusatan perhatian peserta didik kepada guru sebelum guru mulai menyampaikan materi yang berkaitan, selain itu kegiatan pendahuluan juga ditujukan untuk memberikan motivasi dan semangat kepada peserta didik agar selama proses pembelajaran peserta didik lebih antusias. Kemudian kegiatan pelaksanaan dimulai.menyampaikan materi melalui isi dari media Pop Up Box yang dimana terdapat materi interaksi keruangan dalam Negara Negara ASEAN sub bab karakteristik Negara Laos yang di buat secara menarik dan mudah dipahami oleh peserta didik.

Selanjutnya guru memperlihatkan media tersebut di depan kelas. Guru menyampaikan informasi yang terdapat di media Pop Up Box mengenai materi karakteristik Negara laos terkadang guru melemparkan pertanyaan terkait kepada peserta didik, dan peserta didik merespon terkait pertanyaan yang dilontarkan oleh guru. Setelah itu dalam proses pemahaman peserta didik di berikan sejumlah kotak surat yang didalamnya berisikan perintah untuk mengerjakan bersama kelompok masingmasing dimana dalam satu kelompok terdiri dari 5-6 orang. Dikarenakan situasi pandemi Covid-19 untuk kegiatan kelompok dilakukan dengan sistem satu lajur kebelakang bangku dan untuk tempat duduk masih sama, hal tersebut dilakukan agar terhindar dari kerumunan yang menyebabkan salah satu cara penularan virus Covid-19. Setelah peserta berdiskusi setiap kelompok menunjuk satu perwakilan untuk membacakan di depan kelas terkait hasil diskusi yang telah dikerjalan bersama anggota kelompok lainnya. Kemudian kegiatan penutup, guru mengulas kembali sejumlah materi yang sudah disampaikan tadi dan menanyakan terkait pemahaman peserta didik. Kemudian guru memberikan sejumlah motivasi diakhir, dan menyimpulkan materi yang sudah dipelajari bersama serta diakhiri dengan salam dan berdoa.

Dengan demikian dapat disimpulkan bahwa kegiatan pelaksanaan yang dilakukan oleh Ibu Anisa sebagai guru mata pelajaran IPS kelas VIII sesuai yang dikemukakan oleh pendapat para ahli. Teori yang dikemukakan oleh Nana Sudjana (2010) menyebutkan tiga tahap kegiatan dalam proses pembelajaran yaitu pendahuluan, kegiatan inti/pelaksanaan, dan penutup. Dan hal tersebut sejalan dengan kegiatan yang dilakukan oleh Ibu Anisa. Didalam pelaksanaannya Ibu Anisa sebagai guru mata pelajaran IPS kelas VIII 
menggunakan media Pop Up Box dan sudah di laksanakan dimana dapat dilihat pada kgiatan pendahuluan, kegiatan inti, penutup.

\section{Tahap Evaluasi}

Suharsimi Arikunto dan Safruddin Abdul Jabar (2006) mengartikan evaluasi sebagai sebuah proses mengumpulkan informasi tentang bekerjanya suatu hal dan kemudian informasi tersebut digunakan sebagai pertimbangan atau alternatif dalam pengambilan keputusan. Dengan demikian evaluasi dapat diartikan sebagai sebuah proses pengambilan informasi untuk suatu perbaikan pada progam atau kegiatan selanjutnya. Secara umum tidak ada aturan baku dalam penentuan instrument atau bentuk instrument itu sendiri, setiap guru memiliki pandangan dan kriteria yang berbeda dalam penyusunan instrument. Namun secara umum instrument tersebut berupa kolom yang berisi nomor, nama peserta didik, aspek penilaian, dan skor atau nilai (Lestari Puji, dkk: 2019). Berdasarkan hasil penelitian di SMP Bhakti Kudus diketahui bahwa tahap evaluasi berfokus pada tiga ranah, ketiga ranah tersebut antara lain: ranah kognitif, psikomotorik, afektif. Evaluasi pada ranah kognitif dilakukan dengan dengan cara merangkum, dan tanya jawab. Ranah psikomotorik dilakukan dengan cara pengamatan secara langsung saat proses pembelajaran IPS dilaksanakan di kelas. Untuk ranah psikomotorik guru mengamati keaktifan peserta didik disaat pembelajaran berlangsung. Sedangkan untuk evaluasi ranah afektif dilakukan dengan evaluasi berfokus kepada sikap atau karakter yang diharapkan yang dimiliki oleh peserta didik. Dikarenakan untuk mengukur karakter yang merupakan sesuatu yang tidak dapat dinilai secara langsung maka diperlukan sebuah pedoman indikator tertentu yang memberikan gambaran terkait karakter tersebut.

Faktor Penghambat Dan Pendukung Pemanfaatan Media Pop Up Box Didalam Proses Pembelajaran Pelajaran IPS Di Kelas VIII SMP Bhakti Kudus

Penggunaan media pembelajaran sangat membantu dalam proses berlangsungnya pendidikan, dengan bantuan dari media proses pembelajaran akan terbentuk dengan aktif, dam menyenangkan dengan demikian pemilihan statergi yang tepat akan dapat mencapai tujuan dari suatu pembelajaran. Seperti yang diungkapkan oleh Azhar Arsyat bahwa seorang guru dalam memilih suatu media harus sesuai dengan tujuan yang dicapai. Penggunaan media Pop Up Box pada pembelajaran IPS bertujuan untuk mengetahui sejauh mana tingkat pemahaman peserta didik terhadap materi yang diajarkan dan dapat dengan mudah memahami isi materi. Dengan adanya media Pop Up Box pada pembelajaran IPS dapat juga berfungsi sebagai pendorong ketrampilan kreatifitas dan pengetahuan peserta didik. Dalam menyampaikan materi pembelajaran IPS guru guru dibantu oleh media Pop Up Box sebagai alat komunikasi pembelajaran.

Sebuah proses pembelajaran memiliki faktor pendukung dan penghambat yang mempengaruhi keberhasilan dalam suatu pembelajaran. Faktor faktor tersebut dalam banyak hal sering berkaitan dan mempengaruhi satu sama lain. Faktor pendukung mempengaruhi keberhasilan suatu proses pembelajaran, sedangkan faktor penghambat faktor yang mempengaruhi peserta didik dalam meningkatkan pembelajaran menjadi lebih baik dan optimal. Media Pop Up Box dapat dimanfaatkan dalam pembelajaran manakala guru sebagai pengelola pembelajaran yang mahir dalam menggunakan media. Karena penggunaan media bertujuan untuk mempengaruhi para peserta didik mencapai tujuan pendidikan yang telah ditetapkan. Untuk menunjang terjadinya keberhasilan dalam belajar mengajar dibutuhkan beberapa alat yaitu diantaranya adalah media. Menurut Wati (2016) berpendapat bahwa faktor pendukung media yaitu dapat mempermudah penyampaian materi dan menimbulkan interaksi antara peserta didik dan guru, dalam penelitian yang dilakukan di SMP Bhakti Kudus pada proses pembelajaran IPS dengan menggunakan media Pop Up Box, media tersebut sesuai dengan pendapat yang di kemukakan oleh wati (2016) tentang faktor pendukung media. Media Pop Up Box dapat mempermudah peserta didik dalam proses penyampaian materi pembelajaran karena dapat dilihat berkali- kali jika mau menggunakannya dan mudah di simpan, analisa lebih tajam dapat membuat peserta didik lebih faham isi materi tersebut dengan menganalisis yang lebih mendalam dan dapat membuat orang berpikir lebih spesifik tentang isi tulisan. Dengan adanya media Pop Up Box dapat menimbulkan interaksi antara peserta didik dan guru, meningkatkan daya tarik dan perhatian peserta didik. Sedangkan faktor penghambat dari penggunaan media Pop Up Box ialah: 
1. Sekolah SMP Bhakti Kudus belum mengoptimalkan penunjang pembelajaran dari segi prasarana dan prasarana dalam hal ini fasilitas belajar di kelas. Baik dari segi sumber belajar maupun media pembelajaran.

2. Keterbatasan kemampuan setiap peserta didik dalam menerima materi pembelajaran yang berbeda.

3. Selanjutnya dari segi penyampaian materi dengan menggunakan media $P o p U p$ Box guru belum trampil dalam menggunakan media tersebut, merasa gugup dan bingung dalam menggunakan media.

\section{SIMPULAN}

Berdasarkan hasil penelitian tentang pemanfaatan media Pop $U p$ Box dalam pembelajaran IPS kelas VIII di SMP Bhakti Kudus, dapat ditarik kesimpulan:

Pemanfaatan media Pop Up Box di dalam pembelajaran IPS di SMP Bhakti Kudus dilaksanakan melalui tiga tahap. Tahap pertama, yaitu tahap perencanaan, dimana guru merencanakan RPP yang di dalamnya memanfaatkan media Pop Up Box. Tahap kedua, yaitu tahap pelaksanaan dimana guru menerapkan media $P o p \quad U p$ Box pada pembelajaran IPS. Penerapan tersebut melalui tiga tahap kegiatan, pertama kegiatan pendahuluan yang diawali dengan berdoa dan dilanjutkan apersepsi selanjutnya pada kegiatan inti guru menggunakan media Pop Up Box pada saat penyampaian materi dan terakhir kegiatan penutup guru menutup pembelajaran IPS dengan menyimpulkan materi pembelajaran. Pada tahap terakhir yaitu tahap evaluasi, dimana evaluasi berfokus pada tiga ranah. Dan setelah menggunakan media Pop Up Box terdapat peningkatan ranah kognitif, dan psikomotorik dibandingkan menggunakan media papan tulis.

Pemanfaatan media Pop Up Box menemui beberapa faktor pendukung dan penghambat. Beberapa faktor pendukung antara lain: (1) Media Pop Up Box dapat mempermudah proses penyampaian materi pembelajaran dan mudah di simpan, (2) Membuat peserta didik lebih faham isi materi tersebut dengan menganalisis yang lebih mendalam. (3) Dapat membuat orang berpikir lebih spesifik tentang isi tulisan. (4) Media Pop Up Box dapat menimbulkan interaksi antara peserta didik dan guru. Sedangkan untuk faktor penghambat penggunaan media Pop Up Box ialah: (1) Belum mengoptimalkan penunjang pembelajaran dari segi prasarana dan prasarana. (2) Keterbatasan kemampuan peserta didik. (3) Potensi peserta didik dalam menangkap materi sangat berbeda. (4) Guru belum trampil dalam menggunakan media Pop Up Box.

\section{DAFTAR PUSTAKA}

Ahmad, Susanto. 2014. Manajemen Peningkatan Kinerja Guru :Konsep, Strategi, dan Implementasinya. Jakarta : Kencana

Arikunto, Suharsimi.2006. Prosedur Penelitian Suatu Pendekatan Praktik.Jakarta: Rineka Cipta

Azhar Arsyad. 2007. Media pembelajaran. Jakarta: PT. Grafindo Persada

Anjur, Irwanto Posantus. 2016. Skripsi: pemanfaatan media gambar dalam pembelajaran IPS. Universitas PGRI Yogyakarta

Daryanto. 2016. Media Pembelajaran. Yogyakarta: Gava Media

Hamalik, Oemar. 2010. Proses Belajar Mengajar. Jakarta : PT Bumi Aksara

Indonesia, 2013. Permendikbud No 68 Tahun 2013. Kerangka dasar dan struktur Kurikulum SMP/MTs. Jakarta: Sekertariat Negara

Indonesia, 2003. Undang-undang No 20. Tahun 2003. Sistem Pendidikan Nasional. Jakarta: Sekertarian Negara

Indonesia, 2003. Undang-undang No 20 pasal: 37. Tahun 2003. Sistem Pendidikan Nasional. Jakarta: Sekertarian Negara

Kustandi, Cecep. 2011. Media Pembelajaran. Ghalia Indonesia: Bogor

Lestari, Puji, dkk. 2019. Implementasi Penguatan Pendidikan Karakter (PPK) Nasionalisme dan Religius Dalam Pembelajaran IPS di SMP NASIMA Semarang. SOSIOLIUM, Volume 1, Nomor 1.

Lestawi, I. N. 2013. 'Revitalisasi Kearifan Lokal Dalam Kehidupan Beragama Bagi Masyarakat Hindu di Bali'. Kementerian Agama RI. Instritut Hindu Dharma Negeri Denpasar.

Munadi, Yuhdi. 2013. Media Pembelajaran: Sebuah Pendekatan Baru. Jakarta:GP Press Group.

Moleong. 2011. Metodologi Penelitian Kualitatif (Edisi Revisi). Bandung: PT Remaja Rosdakarya

Musfiqon. 2012. Media dan Sumber Belajar. Jakarta. Prestasi Pustaka

Nasution. 1998. Asas asas Kurikulum. Bandung: CV. Jemmass

Nasriya, Tsalats Zaidatul. 2018. Skripsi: Pengembangan Media Pembelajaran 
Explosion Box. Universitas Islam Negeri Maulana Malik Ibrahim

Pramesti, Novena Diana. 2019. Skripsi: Pengembangan media pembelajaran explosion box kelas VIII SMP pada materi sistem pencernaan manusia. Universitas Dharma: Yogyakarta

Sanjaya, Wina. 2010. Statergi Pembelajaran Berorientasi Standar Proses Pendidikan. Jakarta: Prenada Media Group

Sapriya. 2019. Pendidikan IPS Konsep dan Pembelajaran. Bandung: Remaja Rosda Karya

Subana, Sudrajat. 2005. Dasar dasar Penelitian Ilmiah. Bandung: Pustaka

Sudjana, Nana. 2010. Media Pengajaran, Sinar Baru Algensindo: Bandung

Sugiyono. 2017. Metode Penelitian Kuantitatif, Kualitatif dan R\&D. Bandung: PT Alfabeta

Smaldino, dkk. 2008. Instructional Technology and Media for Learning: Teknologi
Pembelajaran dan Media Untuk Belajar: Edisi 9. Penerbit: Prenada Media Group.

Supriyadi. 2011. Statergi Belajar Mengajar. Yogyakarta: Cakrawala Ilmu

Supardi. 2011. Dasar dasar Ilmu Sosial. Yogyakarta: Ombak

Suryani, N. 2018. Media Pembelajaran Inovatif dan Pengembangannya.

Remaja Rosdakarya: Bandung

Suryanti dan Agung S. 2012. Statergi Belajar Mengajar. Yogyakarta: Ombak.

Sumantri, Numan. 2001. Pembaharuan Pendidikan IPS. Bandung: Rosda Karya

Vianda, Ulya. 2020. Pemanfaatan Media Explosion Box Pada Materi Protista Untuk Meningkatkan Hasil Belajar Peserta didik. UIN Ar-Raniry

Wati, Ega Rima. 2016. Ragam Media Pembelajaran. Yogyakarta: Kata Pena 